\title{
Arthropods of the Limarí River basin (Coquimbo Region, Chile): taxonomic composition in agricultural ecosystems
}

\author{
Artrópodos de la cuenca del Río Limarí \\ (Región de Coquimbo, Chile): composición taxonómica en \\ agroecosistemas
}

\author{
Jaime Pizarro-Araya ${ }^{1 *}$, Fermín M. Alfaro ${ }^{1,2}$, \\ Rodrigo A. Muñoz-Rivera ${ }^{3}$, Juan E. Barriga-Tuñon ${ }^{4}$, Luis Letelier ${ }^{5,6}$ \\ Originales: Recepción: 16/08/2019 - Aceptación: 07/05/2020
}

\begin{abstract}
The Limarí valley, located in the Coquimbo Region of Chile, is an important agricultural area that is immersed in the transverse valleys of the Norte Chico. In recent decades, the continuous expansion of agriculture towards dry land zones has favored the migration and establishment of potential pests, such as arthropods, that may affect crops or be zoonotic agents. Based on the limited knowledge we have about the arthropod group present in the Limarí basin, our objective is to describe the taxonomic composition of the assemblage of economically important arthropods inhabiting this basin of the semiarid region of Chile. After reviewing historical data, specimen collections, and the specialized literature, a total of 414 arthropod species were recorded. Of the total number of species recorded, $92.5 \%$ were insects, the most diverse taxon, with 11 orders. Arachnids, in turn, were represented only by Acari with 31 species. The most widely represented orders of insects were Coleoptera, Hemiptera, and Lepidoptera. Within Coleoptera the most species-rich families were, in decreasing order of importance, Curculionidae, Coccinellidae, Cerambycidae, Scarabaeidae, Chrysomelidae (Bruchinae), Ptinidae, and Bostrichidae; within Hemiptera these were Aphididae, Diaspididae, Coccidae, Pseudococcidae, Pentatomidae and Rhopalidae; and within Lepidoptera they were Noctuidae and Tortricidae. We hope this study serves as a starting point for identifying the most diverse arthropod groups and developing pest monitoring and control programs.
\end{abstract}

Keywords

taxonomic structure $\bullet$ insects $\bullet$ Norte Chico $\bullet$ agricultural pests $\bullet$ transverse valleys $\bullet$ arid zones

1 Laboratorio de Entomología Ecológica, Departamento de Biología. Facultad de Ciencias, Universidad de La Serena. Casilla 554. La Serena, Chile.

*japizarro@userena.cl

2 Instituto de Investigación Multidisciplinar en Ciencia y Tecnología. Universidad de La Serena. Chile.

3 Laboratorio de Prospección, Monitoreo y Modelación de Recursos Agrícolas y Ambientales (PROMMRA), Departamento de Agronomía. Facultad de Ciencias. Universidad de La Serena. Ovalle. Chile.

4 Escuela de Agronomía. Facultad de Ciencias, Agrarias y Forestales, Universidad Católica del Maule. Casilla 7-D. Curicó. Chile.

5 Centro de Investigación en Recursos Naturales y Sustentabilidad (CIRENYS), Universidad Bernardo O'Higgins. Casilla 913322. Santiago. Chile.

6 Instituto de Ciencias Biológicas y Núcleo Científico Multidisciplinario, Universidad de Talca. 1 Poniente1141, Casilla 747-721. Talca. Chile. 


\section{RESUMEN}

El valle del río Limarí, situado en la Región de Coquimbo de Chile, es un importante foco de producción agrícola del Norte Chico. En las últimas décadas, la constante expansión de los cultivos agrícolas hacia zonas de secano ha permitido la migración y el establecimiento de potenciales plagas, como los artrópodos, que pueden afectar las producciones agrícolas o constituir agentes en la transmisión de zoonosis. Debido al escaso conocimiento que se tiene sobre el grupo de artrópodos presentes en la cuenca del Limarí, el objetivo del presente trabajo fue describir la composición taxonómica de los artrópodos de importancia económica presentes en esta cuenca del semiárido chileno. Mediante la revisión de bases de datos históricas, colecciones y literatura disponible, se registró un total de 414 especies de artrópodos. El 92,5\% de las especies registradas fueron insectos, los que corresponden al grupo más diverso, con 11 órdenes, mientras que los arácnidos estuvieron representados solo por Acari con 31 especies. Los órdenes de insectos con mayor representación fueron Coleoptera, Hemiptera y Lepidoptera. Las familias con mayor riqueza fueron, en orden decreciente, las siguientes: dentro de Coleoptera, Curculionidae, Coccinellidae, Cerambycidae, Scarabaeidae, Chrysomelidae (Bruchinae), Ptinidae y Bostrichidae; dentro de Hemiptera, Aphididae, Diaspididae, Coccidae, Pseudococcidae, Pentatomidae y Rhopalidae; y dentro de Lepidoptera, Noctuidae y Tortricidae. Se espera que el presente estudio sirva como un catastro inicial para desarrollar programas de monitoreo y control de potenciales plagas.

\section{Palabras clave}

estructura taxonómica $\bullet$ insectos $\bullet$ Norte Chico • plagas agrícolas • valles transversales - zonas áridas

\section{INTRODUCTION}

In Chile, the Norte Chico region extends from $27^{\circ}$ to $32^{\circ} \mathrm{S}$ and encompasses the administrative regions of Atacama and Coquimbo. The area is characterized by the presence of an intermediate depression interspersed with mountain ranges that give origin to transverse valleys that extend from the Andes to the Pacific Ocean (14). These valleys, namely the valleys of Copiapó $\left(27^{\circ}\right.$ to $\left.28^{\circ} \mathrm{S}\right)$ and Huasco $\left(28^{\circ}\right.$ to $\left.29^{\circ} \mathrm{S}\right)$ in the Atacama region and the valleys of Elqui $\left(30^{\circ} \mathrm{S}\right)$, Limarí $\left(31^{\circ} \mathrm{S}\right)$ and Choapa $\left(32^{\circ} \mathrm{S}\right)$ in the Coquimbo region, form a semiarid matrix characterized by scarce and disperse rainfall and the presence of permanent, mixed-regime rivers (14).

Significant among the transverse valleys of semiarid Chile is the Limarí basin, considered to be an economically important food and agricultural area (22) with secondary production activities such as small-scale agriculture, cattle raising and small-scale mining (13). Nowadays the valley surface is covered by forage $(25,456 \mathrm{ha})$, fruit $(20,151 \mathrm{ha})$, grapevine $(8,353 \mathrm{ha})$ and vegetable $(4,753 \mathrm{ha})$ cultivation lands (22). Based on export volumes, the most economically important fruit crops include grapevines $(7,321.7 \mathrm{ha})$, avocado trees $(4,128.0 \mathrm{ha})$, olives $(2,511.2 \mathrm{ha})$ and mandarin trees $(1,573.4 \mathrm{ha})$, which together with other fruit crops account for $46.9 \%$ of the fruit tree species of the Norte Chico $(12,22)$.

The agri-food activity in the Limary valley is directly dependent on the irrigation water storage capacity provided by its three dams (i.e., La Paloma Dam, 748 million m³; Cogotí Dam, 150 million $\mathrm{m}^{3}$; Recoleta Dam, 100 million $\mathrm{m}^{3}$ ) (15). However, as a result of the introduction of novel irrigation techniques, cultivation lands have expanded from the river bank to slopes located at higher altitudes (4), that is, hill sides, that naturally host vegetation whose productivity varies greatly with the seasons and is highly dependent on climate phenomena (37). Once resources in the natural areas become scarce, the newly cultivated lands, which maintain stable vegetable productivity due to artificial irrigation, become favorable areas for the migration of potential pests $(1,2)$.

The establishment of large-scale cultivation systems in a semiarid basin translates into increased vegetable diversity and, consequently, greater availability of habitats and resources for both pests and natural enemies $(3,7)$. For this reason, taxonomical characterization of pest species, including arthropods, is key to get a better understanding of their nature and of the 
potential biological risks of cultivation systems, particularly agricultural ones (38), data which is essential for identifying biological and entomological vulnerabilities in this large agricultural area. Based on the limited knowledge we have about the arthropod group present in the Limarí basin, our objective is to describe the taxonomic composition of the assemblage of economically important arthropods inhabiting this basin of the semiarid region of Chile.

\section{MATERIALS AND METHODS}

\section{Study area}

The study area encompasses the basin of the Limarí River, including the coastal fringe extending north from the mouth of the Elqui River to the mouth of the Choapa River, following the limits of the water divide for the Limarí River basin, and the coastal fringe south of $31^{\circ} \mathrm{W}$ (figure 1); the corresponding limits were defined using 1:250.000 scale maps from the Instituto Geográfico Militar $(29,30)$. The predominant soil types in the area are entisols, aridisols, and inceptisols, all of which show some influence from the vegetation (26). The climate is steppe type, ranging from steppe with abundant clouds in the coast to cold steppe in mountainous areas (27).

The mean annual precipitation exceeds $300 \mathrm{~mm}$ in mountainous areas and reaches $60 \mathrm{~mm}$ to $240 \mathrm{~mm}$ in the lowlands near the coast (16).

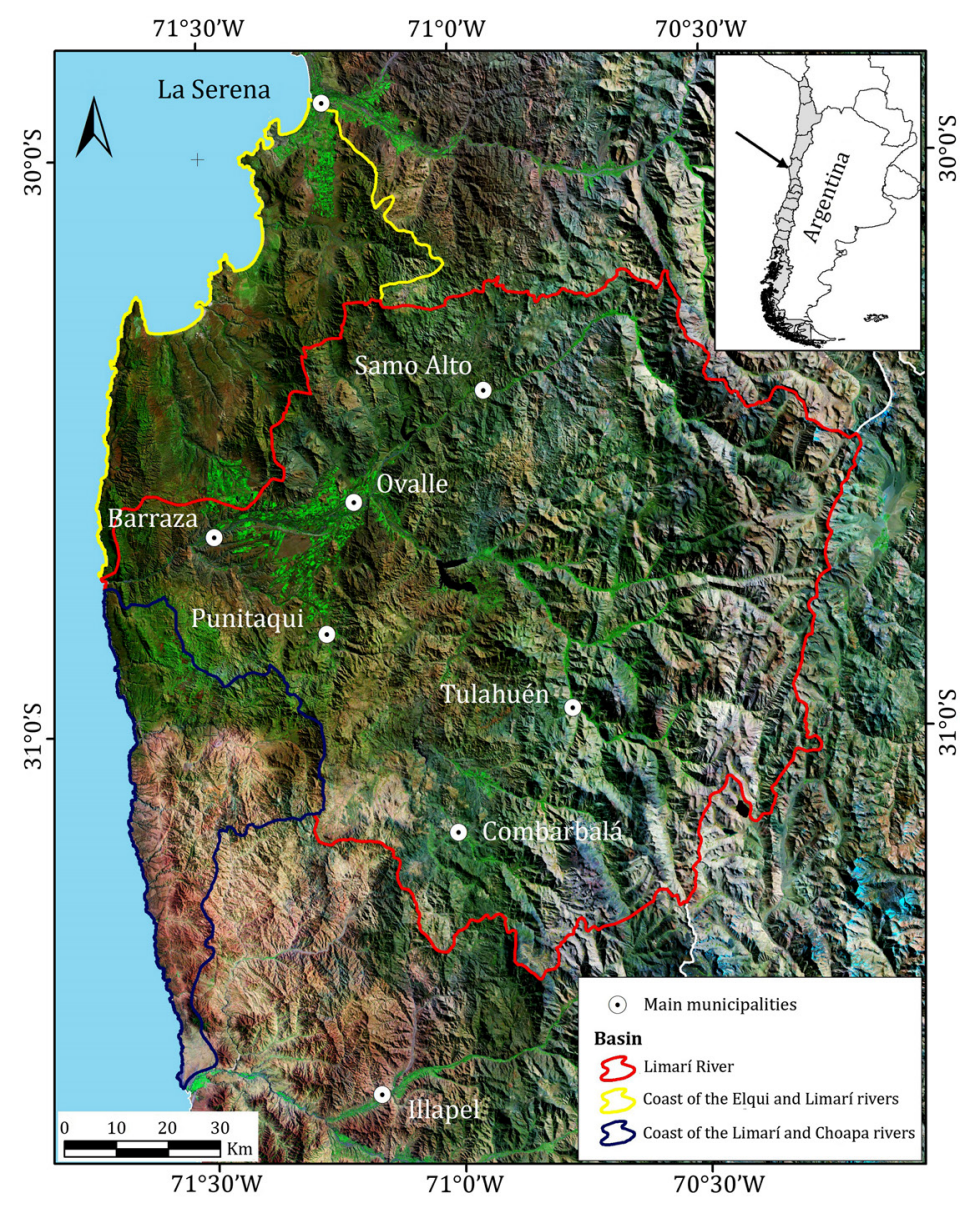

Figure 1. Geographical location of the Limarí basin and coastal basins surrounding. (Coquimbo Region, Chile).

Figura 1. Localización geográfica de la cuenca del Limarí y cuencas costeras circundantes. (Región de Coquimbo, Chile). 
The annual temperature is homogeneous in the coast, but varies in the interior valleys and mountainous areas (16). Far from the influence of the sea, the vegetation in the interior areas corresponds to an interior steppe scrubland $(19,37)$.

\section{Capture methods and data collection}

The taxonomic characterization of economically important arthropods in the Limarí basin was based on distributional data obtained from reference material deposited in the following entomological collections: Juan Enrique Barriga's personal collection (JEBC); Laboratorio de Entomología Ecológica, Universidad de La Serena, La Serena, Chile (LEULS); and Museo Entomológico Luis Peña, Departamento de Sanidad Vegetal, Facultad de Ciencias Agronómicas, Universidad de Chile, Santiago, Chile (MEUC). Additionally, the Servicio Agrícola y Ganadero de Chile (SAG) provided data from entomological prospections conducted between 2009 and 2015 in the Limarí Province. These records were supplemented with distributional data from the literature and data collected using insect-capturing devices, including nets, umbrellas, and fans, between June and October 2015. Additionally, farmers, stakeholders, community leaders, agricultural and orchard workers were interviewd. The information was checked and complemented with literature reviews. The captured material was cleaned, dried, and preserved in alcohol (70\%) until processing and mounting as per Pizarro-Araya et al. (2019 a y b). All the collected material is deposited at the Laboratorio de Entomología Ecológica of Universidad de La Serena (LEULS).

Within Arachnida, Acari was taxonomically identified based on Krantz (1978) and Rojas (2000), whereas Araneae was characterized following Ramírez (1999) and the World Spider Catalog (2020). For Insecta, the taxonomic identification of Coleoptera followed Barriga (1990, 1993 y 2020), Elgueta \& Marvaldi (2006), Vidal \& Guerrero (2007), Solervicens (2014), Moore \& Vidal (2015), González (2019); for Lepidoptera, Artigas (1994), Estay \& Bruna (2002), Angulo et al. (2006); for Hemiptera, Ripa \& Rodríguez (2000), Estay \& Bruna (2002), Castro da Costa (2010); for Diptera, Estay \& Bruna (2002); and for Hymenoptera, Rojas (2005).

\section{RESULTS}

A total of 414 economically important arthropods species were recorded, 92.5\% (383 species) of them insects (Insecta). Arachnids (Arachnida) were only represented by the order Acari (31 species). Insects were the most diverse group, with 11 orders, among which Coleoptera, Hemiptera, Lepidoptera and Hymenoptera had the highest number of taxa (table 1 and figure 2, page 249). The taxonomic composition (genus/species) for these latter groups is as follows: for Coleoptera, the main taxa were Curculionidae (15/21), Coccinelidae (14/21), Chrysomelidae: Bruchinae (7/13), and Scarabaeidae (9/11) (figure 2a, page 249); for Hemiptera, these were Aphididae (17/29), Diaspididae (11/17), Pseudococcidae (4/10), and Pentatomidae (7/8) (figure 2b, page 249); for Hymenoptera, these were Vespidae (3/5) and Pompilidae (1/3) (figure 2c, page 249); and for Lepidoptera, these were Noctuidae $(11 / 14)$, Tortricidae (4/6), Pieridae (3/4), Gelechidae (3/3), and Hesperiidae (3/3) (figure 2d, page 249).

According to the economic importance given for each of the species analyzed in this study, a large percentage of phytophagous species (59.9\%, table 2, page 250), mainly belonging to Acari, Lepidoptera, Hemiptera and Coleoptera, were registered in the basin. Some families of agricultural importance, such as Aleyrodidae, Aphididae, Coccidae, Diaspididae, Margarodidae, and Pseudococcidae (Hemiptera) (figure 2b, page 249), were observed in large agricultural crops in the basin (e.g., vines, oranges, mandarins, lemon trees, avocado trees, walnuts, olive trees, vegetable crops). These organisms can cause direct damage to the crops, since the different stages (adults, nymphs and/or larvae) can feed on both vegetative and fruitful organs of the plants. A smaller but no less important fraction corresponded to the group of predators $(14.7 \%)$ and parasitoids $(2.2 \%)$, mainly represented by Coleoptera (i.e., Coccinellidae), Neuroptera (i.e., Chrysopidae) and Hymenoptera (i.e., Braconidae, Encyrtidae, Ichneumonidae, Platygastridae, Signiphoridae) (table 2, page 250). 
Table 1. Taxonomic composition (families, genera, and species) of economically-important arthropod orders in the Limarí basin (Coquimbo Region, Chile).

Tabla 1. Composición taxonómica (familias, géneros y especies) de órdenes de artrópodos de importancia económica de la cuenca del Limarí (Región de Coquimbo, Chile).

\begin{tabular}{|c|c|c|c|}
\hline Order & Families & Genera & Species \\
\hline Acari & $\mathbf{9}$ & $\mathbf{1 9}$ & $\mathbf{3 1}$ \\
\hline Coleoptera & $\mathbf{2 6}$ & $\mathbf{9 5}$ & $\mathbf{1 3 9}$ \\
\hline Dermaptera & $\mathbf{2}$ & $\mathbf{3}$ & $\mathbf{3}$ \\
\hline Diptera & $\mathbf{8}$ & $\mathbf{1 4}$ & $\mathbf{1 5}$ \\
\hline Hemiptera & $\mathbf{2 3}$ & $\mathbf{8 2}$ & $\mathbf{1 2 5}$ \\
\hline Hymenoptera & $\mathbf{1 4}$ & $\mathbf{2 1}$ & $\mathbf{2 5}$ \\
\hline Lepidoptera & $\mathbf{1 7}$ & $\mathbf{3 8}$ & $\mathbf{4 5}$ \\
\hline Neuroptera & 2 & $\mathbf{5}$ & $\mathbf{5}$ \\
\hline Orthoptera & $\mathbf{4}$ & $\mathbf{6}$ & $\mathbf{8}$ \\
\hline Phasmatodea & $\mathbf{1}$ & $\mathbf{1}$ & $\mathbf{1}$ \\
\hline Psocoptera & 2 & 2 & 2 \\
\hline Thysanoptera & 3 & $\mathbf{1 1}$ & $\mathbf{1 5}$ \\
\hline Total & $\mathbf{1 1 1}$ & $\mathbf{2 9 7}$ & $\mathbf{4 1 4}$ \\
\hline
\end{tabular}
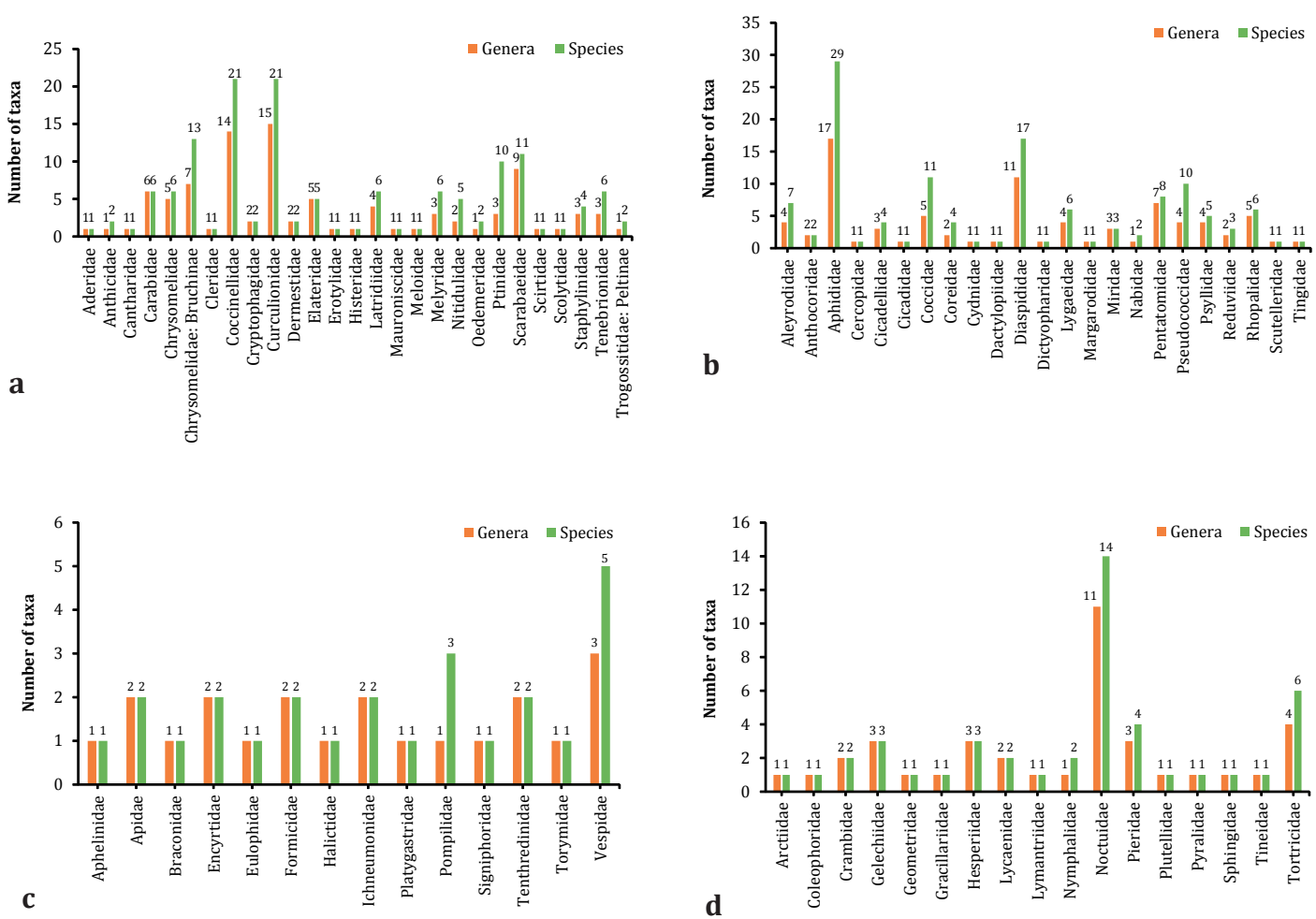

Figure 2. Taxonomic composition (genera and species) of economicallyimportant arthropod orders in the Limarí basin (Coquimbo Region, Chile). a) Coleoptera; b) Hemiptera; c) Hymenoptera; d) Lepidoptera.

Figura 2. Composición taxonómica (géneros y especies) para los órdenes de artrópodos de importancia económica de la cuenca del Limarí (Región de Coquimbo, Chile). a) Coleoptera;

b) Hemiptera; c) Hymenoptera; d) Lepidoptera. 
Table 2. Economic importance of the different arthropod species of the Limarí river basin (Coquimbo Region, Chile).

Table 2. Importancia económica de las diferentes especies de artrópodos de la cuenca del Limarí (Región de Coquimbo, Chile).

\begin{tabular}{|c|r|r|}
\hline Economic importance & Species & Percentage \\
\hline Anthophagous & 1 & 0.2 \\
\hline Attack stored products & 24 & 5.8 \\
\hline Carpophagus & 1 & 0.2 \\
\hline Comercial & 2 & 0.5 \\
\hline Detritivorous & 1 & 0.2 \\
\hline Hematophagous & 2 & 0.5 \\
\hline Mycophago & 5 & 1.2 \\
\hline Omnivorous & 2 & 0.5 \\
\hline Parasitoid & 9 & 2.2 \\
\hline Phytophagous & 248 & 59.9 \\
\hline Pollinator & 17 & 4.1 \\
\hline Predator & 61 & 14.7 \\
\hline Quarantine pest & 19 & 4.6 \\
\hline Saprophagus & 8 & 1.9 \\
\hline Spermophagus & 14 & 3.4 \\
\hline Total & 414 & 100 \\
\hline
\end{tabular}

Some species may constitute quarantine pests for the main markets that import Chilean products. In this study we recorded approximately 19 elements (table 2) that may correspond to species, genera and/or families of quarantine importance for both the US and the European Union. Among these species, insects such as Lobesia botrana (Denis \& Schiffermuller) (Lepidoptera: Tortricidae), Bagrada hilaris (Burmeister) (Hemiptera: Pentatomidae), Aleurothrixus floccosus Maskell, Aleurothrixus porteri Quaintance \& Baker and Aleurothrixus sp. (Hemiptera: Aleyrodidae), these last three correspond to whitefly in citrus, cucurbitaceae and solanaceae.

Other groups of quarantine importance widely registered in the basin were Pseudococcidae (Hemiptera), with the species Pseudococcus calceolariae (Maskell), P. longispinus (Targioni \& Tozzetti), P. meridionalis (Prado), P. viburni (Signoret) and the native mite phytophagus Brevipalpus chilensis Baker (Acari: Tenuipalpidae).

\section{DISCUSSION}

One of the first studies to document potential pests in a valley of Chile's Norte Chico was Pizarro-Araya et al. (2009), who recorded 181 arthropod species (spiders and insects) in three localities of the Elqui valley. Based on a review of historical data, specimen collections, literature data, and entomological captures, Pizarro-Araya et al. (2019a) examined the spatial distribution of economically important arthropods in the Limarí basin (Coquimbo Region, Chile), recording 5,418 arthropod specimens, most of them insects, particularly homopterans and coleopterans. The richness and spatial records were mostly concentrated between the city of Ovalle and the estuary of Punitaqui - the areas with most intense agricultural activity. Also, Pizarro-Araya et al. (2019b) examined the richness of arthropods of forestry and medical-veterinary importance in the Limarí valley, recording 10 families, 39 genera and 51 arthropod species of forestry importance; the xylophagous species of quarantine importance for the US included Cryptotermes brevis (Kalotermitidae), Neoterius mystax (Bostrichidae), Tyndaris planata (Buprestidae), Rhyephenes humeralis (Curculionidae) and Phoracantha recurva (Cerambycidae). Taxa of medical-veterinary importance were represented by 18 species, 14 genera, and 11 families, 9 of them arachnids and 9 insects. The most important arachnid genera were Loxosceles (Sicariidae), Latrodectus, Steatoda (Theridiidae) and Rhipicephalus (Ixodidae), whereas within insects the most important ones were Triatoma and Mepraia (Reduviidae). Some species identified in this 
study corresponded to predators and parasitoids, both groups considered natural enemies of certain pests. These species can help control and reduce pest populations in agricultural crops $(20,32)$.

At present, the Servicio Agrícola y Ganadero (SAG) has under official control six agricultural pests according to the impacts they generate both in international markets and in the environment and biodiversity; these are Lobesia botrana, Bagrada hilaris, Halymorpha halys Stal, Phyllocnistis citrella Stainton, Homalodisca vitripennis (Germar) and Dactylopis coccus (Costa) (35), of which the first two have been registered in the Limarí basin.

As of now, a total of 385 insect species and 24 mite species considered potential agricultural pests have been documented for Chile $(6,23,33)$. In spite of these works, continuous update to these taxonomic inventories is required to identify the inlet pressure and pest establishment in this transverse valley of agricultural and productive importance. We hope that this taxonomic report may be useful for monitoring and controlling pests in newly established crops in a highly modified basin.

\section{ConCLUSIONS}

The economically important arthropods in the Limarí basin included mostly insects (orders Coleoptera, Hemiptera, Lepidoptera and Hymenoptera) and, to a lesser extent, arachnids, the latter represented only by the order Acari. The majority of the species registered in the basin were phytophagous groups (table 2, page 250) that make up a large assemblage of arthropods specialized in and adapted to agricultural crops (e.g., fruit and vegetables crops) of great importance in the Limarí. The total richness recorded in the study area was higher compared to the richness documented for the Elqui basin, probably due to differences in the collection methods used. These data may be complemented with future studies incorporating detailed information on the major economically important groups per crop or sub-basin for a more realistic analysis of the richness level observed in the Limarí basin.

\section{REFERENCES}

1. Alfaro, F. M.; Pizarro-Araya, J.; Cepeda-Pizarro, J.; Bodini, A. 2011. Composición y distribución del ensamble de Orthoptera (Insecta) en una cuenca árida del norte-centro de Chile. Revista de la Facultad de Ciencias Agrarias. Universidad Nacional de Cuyo. 43: 97-110.

2. Alfaro, F. M.; Pizarro-Araya, J.; Letelier, L.; Cepeda-Pizarro. J. 2013. Distribución geográfica de los ortópteros (Insecta: Orthoptera) presentes en las provincias biogeográficas de Atacama y Coquimbo (Chile). Revista de Geografía Norte Grande. 56: 235-250.

3. Altieri, M. A.; Nicholls, C. I. 2007. Diversidad vegetal y estabilidad de las poblaciones de insectos en los agroecosistemas. Biodiversidad y manejo de plagas en agroecosistemas. In: Altieri, M. A. \& C.I. Nicholls. Editorial Icaria. Barcelona. España. 41-52.

4. Álvarez, P.; Reyes, H. 2011. La colonisation de la montagne aride par l'agriculture irriguée: un risque assumé. Sécheresse. 22: 267-274.

5. Angulo, A. O.; Olivares, T. S.; Weigert, G.T. 2006. Estados inmaduros de lepidópteros noctuidos de importancia económica agrícola y forestal en Chile (Lepidoptera: Noctuidae). Universidad de Concepción y CONAF. Ediciones Universidad de Concepción. Concepción. Chile.

6. Artigas, J. N. 1994. Entomología económica. Insectos de interés agrícola, forestal, médico y veterinario. Volúmenes I y II. Ediciones Universidad de Concepción. Concepción. Chile.

7. Attwood, S. J.; Maron, M.; House, A. P. N.; Zammit, C. 2008. Do athropod assemblages display globally consistent responses to intensified agricultural land use and management? Global Ecology and Biogeography. 17: 585-599.

8. Barriga, J. E. 1990. Parásitos y depredadores de larvas de Cerambycidae y Buprestidae (Coleoptera) de Chile. Revista Chilena de Entomología. 18: 57-59.

9. Barriga, J. E. 2020. Coleoptera Neotropical. http://coleoptera-neotropical.org/(Accessed 09.07.2020).

10. Barriga, J. E.; Curkovic, T.; Fichet, T.; Henríquez, J. L.; Macaya. J. 1993. Nuevos antecedentes de coleópteros xilófagos y plantas hospederas en Chile, con una recopilación de citas previas. Revista Chilena de Entomología. 20: 65-91.

11. Castro da Costa, D. 2010. Guía de elementos básicos para el monitoreo y la detección de chanchitos blancos (Pseudococcus viburni) para implementar MIP acorde a los requerimientos BPA. Innova Chile Corfo FDF. Santiago. Chile. 
12. CIREN. 2015. Catastro Frutícola. Principales Resultados. IV Región de Coquimbo/Julio 2015. Centro de Información de Recursos Naturales (CIREN). Santiago. Chile.

13. Cortés, M. E. C. 2016. Drought, environmental degradation, work and education: A brief comment on the current reality of agricultural communities in the Limarí Province, Chile. Idesia. 34: $1-4$.

14. DGA. 1986. Mapa hidrogeológico de Chile. Escala 1:2.500.000. Texto explicativo. Dirección General de Aguas (DGA). Santiago. Chile.

15. DGA. 2015. Información pluviométrica, fluviométrica, estado de embalses y aguas subterráneas. Dirección General de Aguas (DGA). Santiago. Chile.

16. DMC. 2001. Climatología regional. Dirección Meteorológica de Chile (DMC). Santiago. Chile. http://164.77.222.61/climatologia/publicaciones/Climatologia_regional.pdf (Accessed 09.07.2020).

17. Elgueta, M.; Marvaldi, A. E. 2006. Lista sistemática de las especies de Curculionoidea Insecta: Coleoptera) presentes en Chile, con su sinonimia. Boletín del Museo Nacional de Historia Natural. 55: 113-153.

18. Estay, P.; Bruna, A. 2002. Insectos, ácaros y enfermedades asociadas al tomate en Chile. Colección Libros $N^{\circ}$ 7. Instituto de Investigaciones Agropecuarias. Santiago. Chile.

19. Gajardo, R. 1993. La vegetación natural de Chile. Clasificación y distribución geográfica. Editorial Universitaria. Santiago. Chile.

20. Godfray, H. C. J. 1994. Parasitoids: Behavioral and Evolutionary Ecology. Princeton University Press Books. Princeton.

21. González, F. G. 2019. Lista actualizada de Coccinellidae de Chile. http://www.coccinellidae.cl (Accessed 09.07.2019).

22. INE. 2007. Censo Agropecuario y Forestal 2007. Instituto Nacional de Estadísticas (INE). Santiago. http://www.ine.cl/canales/chile_estadistico/censos_ agropecuarios/censo_ agropecuario_07_comunas.php (Accessed 09.07.2020).

23. Klein, C.; Waterhouse, D. F. 2000. Distribution and importance of arthropods associated with agriculture and forestry in Chile. Aciar Monograph № 68. Canberra. Australia.

24. Krantz, G. W. 1978. A manual of Acarology. Corvallis. Oregon State University. Oregon. SA.

25. Moore, T.; Vidal, P. 2015. Los Bupréstidos de Chile. Ediciones Universidad Católica de Chile. Santiago. Chile.

26. Morales, L.; Canessa, F.; Mattar, C.; Orrego, R.; Matus, F. 2006. Caracterización y zonificación edáfica y climática de la Región de Coquimbo, Chile. Revista de la Ciencia del Suelo y Nutrición Vegetal. 6: 52-74.

27. Novoa, J. E.; López, D. 2001. IV Región: El escenario geográfico físico. In: Squeo, F. A.; Arancio, G.; Gutiérrez, J. R. (eds.). Libro rojo de la flora nativa y de los sitios prioritarios para su conservación: Región de Coquimbo, La Serena. Ediciones Universidad de La Serena. La Serena. Chile. 13-28.

28. Pizarro-Araya, J.; Cepeda-Pizarro, J.; Barriga J. E.; Bodini, A. 2009. Biological vulnerability in the Elqui Valley (Coquimbo Región, Chile) to economically important arthropods. Ciencia e Investigación Agraria. 36: 215-228.

29. Pizarro-Araya, J.; Alfaro, F. M.; Muñoz-Rivera, R. A.; Barriga-Tuñon, J. E.; Letelier, L.; Tirado, C. 2019a. Distribución espacial de artrópodos en agroecosistemas de la cuenca del río Limarí (Región de Coquimbo, Chile). Revista de Geografía Norte Grande. 72: 133-144.

30. Pizarro-Araya, J.; Alfaro, F. M.; Muñoz-Rivera, R. A.; Barriga, J. E.; Letelier, L. 2019b. Arthropods of forestry and medical-veterinary importance in the Limarí basin (Coquimbo region, Chile). Ciencia e Investigación Agraria. 46 (1): 40-49.

31. Ramírez, M. J. 1999. Orden Araneae. In: Crespo, F. A.; Iglesias, M. S.; Valverde, A. C. (eds.). El ABC en la determinación de artrópodos I. Ediciones CCC Educando. Buenos Aires. Argentina. 39-59.

32. Ramos Sanz, M.; Lanfranco Leverton, D. 2010. El complejo de parasitoides de la polilla del brote del pino en Chile: pasado, presente y posible escenario futuro. Bosque. 31(2): 100-108.

33. Ripa, R.; Rodríguez, F. 2000. Plagas de cítricos, sus enemigos naturales y manejo. Colección Libros $\mathrm{N}^{\circ} 3$. Instituto de Investigaciones Agropecuarias. Santiago. Chile.

34. Rojas, S. 2005. Control biológico de plagas en Chile. Historia y avances. Colección Libros N 12. Instituto de Investigaciones Agropecuarias. Santiago. Chile.

35. SAG. 2019. Plagas cuarentenarias presentes (bajo control oficial). https://www.sag.gob.cl/ambitosde-accion/plagas-cuarentenarias-presentes-bajo-control-oficial (Accessed 09.07.2020).

36. Solervicens, J. 2014. Coleópteros de la Reserva Nacional Río Clarillo, en Chile Central: taxonomía, biología y biogeografía. Corporación Nacional Forestal (CONAF). Santiago. Chile.

37. Squeo, F. A.; Arancio, G.; Gutiérrez, J. R. 2001. Libro rojo de la flora nativa y de los sitios prioritarios para su conservación: Región de Coquimbo. Ediciones Universidad de La Serena. La Serena. Chile.

38. Squeo, F. A.; Tracol, Y.; López, D.; León, M.; Gutiérrez J. R. 2008. Vegetación nativa y variación temporal de su productividad en la provincia de Elqui. In: Cepeda-Pizarro, J. (ed.) Los sistemas naturales de la cuenca del río Elqui (Región de Coquimbo, Chile): Vulnerabilidad y cambio del clima. Ediciones Universidad de La Serena. La Serena. Chile. 168-191. 
39. Vidal, P.; Guerrero, M. 2007. Los Tenebrionidae de Chile. Ediciones Universidad Católica de Chile. Santiago. Chile.

40. World Spider Catalog, 2020. World Spider Catalog. Version 21.0. Natural History Museum Bern. http://wsc.nmbe.ch (Accessed 09.07.2020).

\section{ACKNOWLEDGMENTS}

Our acknowledgments to Adiel R. Cayo (Servicio Agrícola y Ganadero, División de Protección Agrícola y Forestal) for allowing us access to SAG data. Also, our thanks to Mario Elgueta (MNHN) and Danilo Cepeda (MEUC) for providing facilities to examine the collections. We thank two anonymous reviewers for their suggestions to improve this paper.

Jaime Pizarro-Araya acknowledges the financial support of the DIDULS/ULS, throught the project PR19231210 of Universidad de La Serena, La Serena, Chile. 